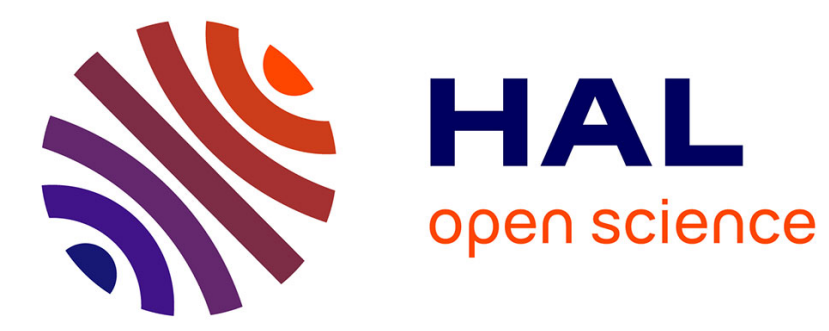

\title{
Short-term matters: the determinants of reforms of the core democratic rules
}

\author{
Camille Bedock
}

\section{To cite this version:}

Camille Bedock. Short-term matters: the determinants of reforms of the core democratic rules. European Political Science Review, 2016, 8 (1), pp.73-93. 10.1017/S1755773914000411 . hal-02266770

\section{HAL Id: hal-02266770 \\ https://hal.science/hal-02266770}

Submitted on 16 Aug 2019

HAL is a multi-disciplinary open access archive for the deposit and dissemination of scientific research documents, whether they are published or not. The documents may come from teaching and research institutions in France or abroad, or from public or private research centers.
L'archive ouverte pluridisciplinaire HAL, est destinée au dépôt et à la diffusion de documents scientifiques de niveau recherche, publiés ou non, émanant des établissements d'enseignement et de recherche français ou étrangers, des laboratoires publics ou privés. 


\section{SHORT-TERM MATTERS: THE DETERMINANTS OF REFORMS OF THE CORE DEMOCRATIC RULES}

\section{Camille Bedock}

\section{Abstract}

Current theories on institutional change tend to interpret it either as the result of long-term gradual trends, or of disrupting shocks following periods of punctuated equilibrium. Less is known about the moments in which change is more frequent. Focusing on the short-term determinants of reforms of core democratic rules in consolidated democracies, the article shows that proximate shifts in the electoral arena have a distinctive impact on the number of institutional reforms that are adopted in a legislature. Using the empirical and theoretical findings of the literature on electoral reform, the article develops a model tested in statistical analyses aggregating a large sample of institutional reforms in Western European democracies between 1990 and 2010. The results show that rising electoral uncertainty measured by volatility, and the change of preferences of the actors in power measured by the advent of new forces in government lead to the adoption of more institutional reforms. These results appear consistent when some categories of reform are added or subtracted, giving confidence that this model can be applied to a wide range of institutional reforms.

Keywords: electoral reform, institutional reform, democracy, Western Europe 
Two strands of theories have dominated the agenda of research on institutional reforms in consolidated democracies. Authors have mainly shown evidence that change is either the result of gradual trends in the long run or of changes following periods of punctuated equilibrium. Streeck and Thelen called the former "transformation without disruption" $(2005,4)$ and Steinmo "evolution of modern states" (2010), whereas Baumgartner and Jones qualified the latter as "disjoint[ed], episodic, and not always predictable" change $(2012,1)$. These two theories have provided major contributions in describing patterns of change; the role of path dependency and policy entrepreneurs, and the evolution of framing in policy reforms. However, in these two perspectives, change is either imperceptible, or very sudden and hard to predict. Indeed, these theories have not investigated in depth the moments in which change is more likely. The short-term factors setting in motion these processes of change at a particular moment still remain, in many ways, a blind spot, that this article seeks to investigate. Democratic institutional systems can be conceived as "explicit products of social choices" (Bawn 1993, 965), i.e. as the product of conscious decisions by the political elites and other actors. Therefore, there are strong reasons to believe that parties do adapt the institutions, either as a result of the changes of their environment, or as a result of a change of preferences of elites in power. Consequently, it is logical to expect that short-term shifts and factors have a significant impact on the propensity to adopt institutional reforms, and on their number.

The lack of theories predicting moments of institutional change was not least the result of the absence of cross-national, longitudinal and multidimensional studies on institutional reforms in Western European democracies. The literature on electoral system change, emerging in the 1990s, has shed a new light on the topic of institutional change by providing fruitful insights, both empirical and theoretical, to answer the question of the impact of shortterm determinants on the reforms of core democratic institutions. There has been, however, no attempt to expand its conclusions to other categories of reform. This paper aims at bridging this gap to answer the seemingly trivial, but under-investigated question: do the short-term changes in the electoral environment, and the shifts in public opinion about the institutional system, impact the frequency of reforms in established democracies?

This article focuses specifically on established democracies of Western Europe in the last two decades, i.e. on democracies in which the general architecture of the democratic political system is consolidated and durable. Secondly, the analysis is centred on the reforms of the formal core democratic rules. These rules can be defined as the formal political rules 
regulating the direct relationship between elites, parties, and citizens enacted by the national parliaments. These reforms can range from the electoral systems to the territorial organization of the state, to constitutional review or provisions for direct democracy. This article has chosen to deal with a large sample of reforms including a wide range of categories of institutions, in order to build a hard test for the validity of our theory. Needless to say, it is really hard to disentangle which changes would have happened no matter what, and which ones are triggered by particular short-term circumstances. Greif and Leitin have noted the difficulty to account for endogenous change not triggered by environmental changes, considering that certain parameters are fixed at a given time, variable in the long-run, therefore leading to change over time (2004). Even though this article cannot account for these complex dynamics, it can, and does address, the impact of particular short-term shifts on the number of reforms witnessed.

\section{The relationship between short-term shocks and institutional reform}

It is not expected that short-term determinants provide the entire explanation for the choice to have recourse to institutional change, or even that they are the main determinant at stake. However, they constitute one important part of the picture, in that they mediate the link between the short-term evolution of the context in which parties compete and the change of formal institutions. Previous works on electoral system change offer helpful insights to understand this link.

When studying electoral system change, the main sets of explanations dealing with the determinants of change have been twofold: explanations of change analyzing triggers external to the interactions of the actors within the institutional system, and explanations of change based on the internal interactions of the actors within the system. The first set of explanations identifies "reform-prone" conditions. The second set of explanations starts with the assumption that not all countries are equally sensitive to the impact of the short-term factors.

\section{The impact of exogenous triggers on institutional change}

Early studies on electoral reforms were developed as a result the concomitance of three major electoral reforms in 1993 in Japan, Italy, and New Zealand. These three countries were struck by a period combining intense political dissatisfaction and rapid electoral change, and the literature that developed to explain the new electoral systems adopted focused on 
these two intertwined aspects (for a synthesis, see Gallagher, Mitchell, 2005, and Renwick 2010). These findings on the role of political crisis, however, have not often been systematized in large-N studies. Secondly, the "crisis" explanations of institutional change deal with exceptional situations rather than with everyday politics. Indeed, the context in which the 1993 electoral reforms took place was uncommon in many ways, as the Japanese, Italian and New-Zealander systems had shown signs of malfunctioning (corruption and low governability for Japan and Italy, reversed majorities for New Zealand) for quite a few years. The following question remains unanswered: what would be the link between "relative" political crisis and institutional change, i.e. between periods in which the political system is contested, but not truly endangered?

Norris (2011) has investigated the statistical link between democratic legitimacy understood broadly and electoral reform. Comparing the countries included in the World Values Survey between 1993 and 2004, she shows that there is a relationship between what she calls "democratic aspirations" (support for democratic ideals) and electoral reform. She does not find evidence of a link between confidence in institutions, evaluation of the democratic performance of a country, and electoral reform. Norris includes a great variety of countries and studies the link between the overall level of democratic legitimacy and reform (i.e. the long-term impact of this factor), rather than the impact of short-term shifts on the propensity to reform. Whereas Norris studies the level of legitimacy as an "inherent" factor of reform (Shugart in Shugart and Wattenberg 2003), one might argue that shifts in the level of trust in political institutions and overall appreciation of the democratic performance might be “contingent" factors for reform (i.e., short-term triggers).

The literature on electoral system change has progressively attempted to go beyond crisis explanations by evaluating the link between shifts of political competition, the previous state of the party system, and electoral reforms. Several authors have "reversed" Duverger's laws (Benoit 2007, Colomer 2005), turning around the common assumption that electoral laws shape electoral outcomes, and ultimately, party systems. Doing so, these authors have shown that, in countries such as Belgium or the Netherlands for example, which adopted proportional representation at the beginning of the $20^{\text {th }}$ century, the proliferation in the parliament of multiple parties preceded the adoption of PR. A number of authors focus on the switch from Single-member plurality to Proportional representation in Europe at the beginning of the $20^{\text {th }}$ century. They show how the emergence of socialist parties as a threat to incumbent elites (Rokkan 1970, Boix 1999), the correction of partisan biases caused by majoritarian electoral 
systems after the extension of electoral franchise (Calvo 2009), or contexts of extreme political uncertainty for the main party over its future electoral success (Andrews and Jackman 2005), have led to proportional electoral reforms in Western Europe.

Andrews and Jackman provide a very valuable piece of research for our purposes here. They demonstrate how uncertainty encourages short-termist behavior of political parties, and miscalculations about the effects of new institutional rules. They argue: "For political actors to engage in reform of the procedures by which they won in the first place, they must come to believe either that existing arrangements will adversely affect their future prospects for winning, or that they face considerable uncertainty, or both" (Andrews and Jackman 2005, 66). The same study has also established a clear link between uncertainty and electoral shifts. Focusing on the more recent period, Remmer shows how in Latin-America over the last decades, the degree of electoral volatility as well as the variation in the effective number of political parties contribute to explain the frequency of electoral system change (2008).

Finally, some authors have analyzed a fourth factor: the impact of winning and losing elections for individual and party support for change. There have been two main interpretations of the impact alternation on the support for reform. On the one hand, some authors argue that different parties hold different preferences regarding reforms, and that some parties are, for normative or strategic reasons, more prone to support reform than others. On the other hand, other authors develop a slightly more complex interpretation arguing that incumbency had a systematic effect, leading parties that have been in power for a long time to be less reform-prone. Regarding the first interpretation, a number of accounts have also introduced a simple, but central aspect: that governing and opposition parties tend to have different preferences regarding the ideal electoral system. This conclusion is important, in that the previous accounts on electoral system change focused mainly on the self-interested motivations of political actors (Pilet 2008, Rahat 2004), arguing that electoral systems are redistributive in essence in that it implies winners and losers (Tsebelis 1990). More recent works show that normative motivations about the "best" system, regardless of self-interest and ideology, are central to explaining the positions of individuals and parties on electoral reforms (Bol 2013). Dealing with minor electoral reforms, Jacobs and Leyenaar (2011) have already demonstrated with the example of the Netherlands that, when the consequences of a reform for the distribution of powers are unclear for political parties, their support or opposition to reform was more likely to be the consequence of their normative conceptions about the desirability of a particular reform. 
The second interpretation of alternation, resulting mainly from studies of the individual opinions of MPs on electoral reforms, has demonstrated a consistent link between the fact of being an incumbent, being in the majority, and a lowest support for electoral reforms (Bowler, Donovan, and Karp 2006). This result confirmed previous findings dealing with the support of political elites for the adoption of direct democracy mechanisms, in which Bowler, Donovan and Karp showed that incumbents and members of governing parties were significantly less supportive of such reforms (2002). In a similar vein, Bol and Pilet demonstrate, analyzing the positions of parties on 13 electoral reform debates, that parties that have spent more than $60 \%$ of the time in government in the last 25 years were significantly more risk-averse and more supporting of the existing electoral arrangements, no matter what the expected consequences of the reform were in terms of seats (2011).

To summarize, theoretical and empirical links have been established between situations of political crisis, shifting support for the democratic system, rising electoral uncertainty, winner and loser status, and the propensity for electoral system change. These four factors can be thought of as four facilitating conditions for institutional reforms. I argue that these factors also apply to a wider set of reforms, including a broad range of reforms of the core democratic rules. In fact, there are strong reasons to believe that these factors should play an even stronger role for democratic reforms in general. Electoral system change is a rather pure example of redistributive reform involving zero-sum games. Elites have strong vested interests in the existing electoral systems, but the existing literature has already proven, in the circumstances examined above, that these interests and other barriers can be overcome and lead to reform. More and more authors insist on the fact that, outside of outcome-contingent motivations (based on the expectations about the expected consequences of a reform), actcontingent motivations (based on the expectations about the consequences of the very act of supporting a reform) are central in explaining the support for democratic reforms (Renwick 2010; 2011). In the case of reforms where the consequences, in terms of distribution of power, are more uncertain than pure redistributive reforms such as electoral reforms, elites should also base their judgments on act-contingent motivations and pay strong attention to exogenous changes, such as crisis, electoral shifts, and voter satisfaction to make up their mind. In addition, the literature on electoral system change has also. early on, demonstrated that not all institutional systems are equally sensitive to short-term shocks and vulnerable to change.

\section{Endogenous factors of change: the varying vulnerability of different systems towards change}


Shugart has first suggested the interaction between exogenous and endogenous factors during processes of electoral reforms, arguing that electoral reforms are the result of the conjunction between what he calls "contingent" events, and "inherent" characteristics (an electoral system considered as extreme for the dimensions of personalization of the votes and the concentration of power in the government, Shugart in Shugart \& Wattenberg 2003). He has shown that both Italy and Japan, before the reforms of the 1990s, displayed extreme characteristics regarding the personalization of votes that fuelled reform in combination with corruption scandals and political crisis. Other authors, working on the early adoption of PR in Europe, have shown that, in addition with the exogenous factors such as socialist vote or electoral uncertainty, the switch to PR was more likely in countries using majority systems than in countries using plurality systems (Blais, Dobrzynska, and Indridason 2004). These authors argue, indeed, that majority systems imply a more fragmented party system, more coalition governments, higher uncertainty over the electoral outcomes and strategies, which all lead to stronger incentives to adopt PR.

In this article, I investigate the impact of short-term shocks in terms of the institutional change that might differ across systems, once the difficulty to reform has been controlled for. This idea is closely linked with the theory of the determinants of policy stability, that is the veto-players approach, introduced by Immergut (1990) and systematized by Tsebelis. Tsebelis's core argument posits that "to change the legislative status quo, a certain number of individual or collective actors have to agree to the proposed change" $(2002,2)$. Consequently, the opportunities to change the status quo depend on the number of veto players and on the ideological distance between them. He concludes by predicting that "the countries with many veto players will have policy stability, while the ones with one veto player may have instability" (2002, 5). Institutions are typically defined as "stable, valued, recurring patterns of behaviour" (Huntington 1965). Many authors have argued that changing institutions is (even) harder than changing policies (Colomer 2001, 235): "Standard models in political science and public policy studies basically focus on three elements: citizens' preferences, political party's or candidate's positions, and institutional rules. The typical assumption is that the set of institutional rules is the most stable of these elements". Using the case of electoral reforms in Belgium, authors such as Hooghe and Deshouwer (2011) also demonstrate that the barrier constituted by veto players is very difficult to overcome most of the time. Empirically, too few longitudinal and cross-national studies on institutional reforms have been conducted to be able to accept or to reject the postulate that policy change works in the same way as 
institutional change. Therefore, it is necessary to control for the impact of partisan veto players (number of parties in government) and institutional veto players (here approximated by controlling for country effects) on the number of reforms.

\section{Hypotheses}

The main theoretical assumptions of the article can be summarized quite simply. Drops in the satisfaction with the democratic system, rising electoral uncertainty, and the arrival in power of new political forces with distinctive preferences encourage institutional reforms. This study enquires about three main variables: the variation in the support for the functioning of the democratic system (measured by shifts of satisfaction with democracy), the rise of electoral uncertainty (measured by shifts of volatility), and the change of preferences of the actors getting into government (measured by alternation). The two first explanatory variables translate changes in the environment in which the political parties compete, while the third one is focused on shifts of preferences of actors in power. The number of veto players, the level of constitutional rigidity, the ideological orientation of the governments in the legislature, and economic growth are used as control variables.

H1. When the level of satisfaction with the way democracy is working drops, the number of institutional reforms adopted in a legislature increases.

Expanding the assumptions of Norris, this first hypothesis posits that when support for the democratic system drops, the pressure to adopt institutional reforms is stronger, as parties have to react to public dissatisfaction with the democratic system through institutional change. This postulates, firstly, that a drop in the level of political support translates the perceptions of the malfunctioning of the institutional system, and of dissatisfaction of citizens about the way it works. Secondly, it posits that political parties are actually able to perceive these drops and to react to them.

H2. When the level of volatility in the electoral arena rises, the number of institutional reforms adopted in a legislature increases.

The level of volatility can be thought as the tangible expression of shifts of electoral preferences from one election to another, and of the level of electoral uncertainty in which political actors compete. Each political system has an inherent level of volatility linked with 
the structure of its party system. The rise in the level of volatility compared to this "structural" level, on the other hand, is the translation of rising uncertainty about the balance of power between the different parties. This in turn may well be the result of dissatisfaction with the political system, as illustrated, for example, by the unprecedented levels of volatility observed in Italy in 1994, or in Ireland in 2011, in the aftermath of a very severe crisis of legitimacy for political elites. In such a case, volatility implies a level of uncertainty affecting all parties. It might also be the consequence of dissatisfaction with the incumbents' governing performance. In both scenarios, I hypothesize that when the level of volatility rises from one election to another, one should witness more institutional reforms in the following legislature.

H3. When political actors previously in opposition come into power, the number of institutional reforms adopted in a legislature increases.

Thirdly, I expect that political alternation, as it brings to power parties that were previously part of the opposition in power, is a strong incentive for institutional reforms. Alternation provides, to some, political opportunities that they did not have during their time in opposition to carry on reforms. This assumes that governing and opposition parties have built over time different preferences upon institutional reforms. This hypothesis also implies that when previous losers come into government, they are provided with political opportunities to change a system they were less satisfied with than previous incumbents, expanding the conclusions about the fact that parties previously in opposition are more reformist and less risk-averse. Alternation is therefore understood here, primarily, as a switch of preferences of the parties composing the government. ${ }^{1}$

\section{Variables and model specification}

In order to test for the three hypotheses stated above, and the expected relationship between shift of political support, rising political uncertainty, alternation, and institutional reforms, the dependent variable I examine here, is the number of institutional reforms adopted in 116 legislatures in 18 Western European democracies from 1990 to 2010, first drawing a model for all reforms adopted in that period, then evaluating the robustness of the model and its sensitivity to the categories of reforms included.

\section{The dependent variable: the number of institutional reforms adopted by legislature}


This article uses the database "Institutional Change in Advanced European Democracies", collected by Alex Wilson and developed within the realm of the SIEPOL research project (Seclusion and Inclusion in the European Polity: Institutional Change and Democratic Practices) directed by Peter Mair and Adrienne Héritier. It covers over 20 years of institutional reforms (1990-2010) in 18 European countries that democratized before 1989: Austria, Belgium, Denmark, Finland, France, Germany, Greece, Iceland, Ireland, Italy, Luxembourg, Netherlands, Norway, Portugal, Spain, Sweden, Switzerland, and United Kingdom. ${ }^{2}$ The dataset encompasses six categories of institutional reform: electoral system reform, parliamentary reforms, federal reforms or reforms of decentralization, direct election of the head executive at the national or local level, provisions for referendums and citizens' initiative at the national level, and finally, the regulation of the access to suffrage. The interest of this dataset is to cover a wide, although of course non exhaustive, range of reforms of the core democratic rules. Some of the institutions identified, for example, by Lijphart (1999), such as constitutional review, are unfortunately absent. Others, including reforms of direct democracy, are included. Although the aim of the SIEPOL database was to be as exhaustive as possible for the six dimensions included, some reforms may have been omitted. Despite its limitations, the sample of reforms is however the largest currently available.

It is important to note that what counts as a "case" of reform is the modification of the formal rules on one of the six dimensions. This means that if one single law reforms three different dimensions at once, it is considered that three reforms took place, just as if three different laws are adopted. For example, France adopted a constitutional reform in 2008 that contained at once a parliamentary reform, the introduction of constituencies for citizens living abroad, and new provisions about the organization of popular referendums, that were included in the database as three reforms (Bedock, Mair, and Wilson 2012). In the following regressions, the unit of analysis is the legislature and the dependent variable the number of reforms adopted in a given legislature. For the models taking into account all the reforms, this number ranges from zero to 7 (Table 1), with almost two thirds $(63 \%)$ of the legislatures comporting at least one institutional reform. The number of reforms adopted was preferred to a different dependent variable such as a dummy variable reform/no reform. Statistically, it offers a much more sensitive measure, without assuming arbitrary thresholds, considering for 
example, that the crucial difference to investigate is between zero reform and some reforms. The literature presented above has mainly focused on the occurrence of reform rather than on its frequency. Substantively, however, it makes sense to focus on the number of reforms insofar as the database at our disposal accounts for many more reforms than the existing datasets. Indeed, this dataset enables the evaluation not only the impact of a given variable on reform vs. no reform, but also its impact on the number of reforms more generally. ${ }^{3}$ Moreover, the choice to aggregate the adopted reforms avoids the composition of the different dimensions of reform from affecting the statistical results, since each reform is taken into account.

The first question that arises is to find the appropriate method for investigating this dependent variable, characterized by several aspects: its distribution is not normal or discrete, and it constitutes count data.

(Table 1 around here)

\section{Specification of the model}

The analysis has been conducted using negative binomial regression, a subcategory of event count models. Event count models are statistical models in which the dependent variable is a count of events, here, the number of institutional reforms adopted in a given legislature, therefore consisting of discrete, nonnegative integer numbers. They constitute a generalization of the linear model. The traditional OLS regression cannot account for the discreteness and functional form of the dependent variable, which would lead to biased estimators. These models are estimated using maximum likelihood.

To build adequate statistical models based on this dependent variable, the negative binomial regression was chosen over the poisson regression, because of the issue of overdispersion of the data (see Appendix 3). Indeed, poisson regressions have stringent requirements, i.e. that the conditional mean is equal to the conditional variance. The existence of over-dispersion can be interpreted as the violation of the requirement that counts are independent from one another (Hilbe 2011, 2). Its consequences on the estimators can be interpreted in a similar way as the violation of the assumption of homoskedasticity in the linear regression model, meaning that the goodness of fit of the model is overestimated (Cameron and Trivedi 2001). The overall fit of the models was estimated using the likelihood 
ratio test which compares the fit of the estimated model with a null model where all parameters are held at zero.

\section{Explanatory variables and control variables}

The first explanatory variable concerns the shift in the satisfaction with the way democracy functions. Dalton has distinguished between no less than five objects of political support: confidence in public authorities (parties, politicians), confidence in political institutions (government, parliament), the evaluations of the regime's performance (satisfaction with the functioning of the democratic system), support for democratic principles, and finally, support for the political community. While the shifts of the first aspect express "no more than dissatisfaction with the incumbents in office, a normal and healthy aspect in democratic process" (Dalton 1999, 57), and the two last aspects, the support for the polity itself- which can be considered as unproblematic in consolidated Western democraciesthe second and the third dimensions of political support are interesting in the perspective I follow. Ideally, testing for the impact of shifting support for political institutions, and satisfaction with the way democracy is working in a given country, could provide the appropriate answers to the questions of the link between shift of support and institutional reforms. However, assessing appropriately the shifts between one legislature and another would require a large number of data points in time, ideally each year. Such data only exists for satisfaction with democracy, meaning that I will restrict the analysis to this aspect of political support. The variable used is the shift in percentage of the aggregate level of respondents in a given country who say they are "very satisfied" or "fairly satisfied" to the trend question of the Eurobarometer "are you satisfied with the way democracy is functioning in your country?"

The second explanatory variable is the shift in percentage in the level of total volatility, defined by Bartolini and Mair as the "measure of the net electoral change between two consecutive elections" (1990, 17), and using the Pedersen index (1979). This second explanatory variable is a proxy for the level of uncertainty of each election, with the underlying idea that the more important the shifts between one election and the other, the more unstable the party system and the electoral environment.

The third and final explanatory variable is political alternation at the beginning of a given legislature. This is a dummy variable defined as the concomitance of a change in the political orientation of the cabinet and a change in the head executive. The ideological 
orientation of the cabinets in each legislature is the result of a specific literature review to correctly classify parties in each country (See online appendix 2).

The first control variable is the aggregated number of partisan veto players in the government for each legislature (measured as the number of parties present in the government), therefore controlling for eventual effects of the government configuration on the occurrence of institutional reforms. This measure of partisan veto players has the advantage of being very simple, and as reliable as the more complex measures that have been tested in the literature, as shown by Roller (2005). Since this data is composed of legislatures by country, I also control for country effects by including 18 dummy variables for each of the countries included. The third control is the ideological orientation of the cabinets in the legislature: left/center left, right/center right, and grand coalition. Given the development of the reflection about the link between economic crises, political legitimacy and institutional reforms, I also included the average level of economic growth in each legislature as a control variable, although the timeframe of this paper stopping in 2010 does not really enable me to conduct precise investigations on this point. $^{4}$

\section{Results}

In the six models presented here (Table 2), the dependent variable is the total number of reforms adopted by legislature, and the results are reported using incidence rate ratios for matters of readability and interpretation, with the $95 \%$ confidence intervals in parentheses to evaluate the uncertainty of the coefficients.

\section{General model: the centrality of shifts in the electoral arena}

(Table 2 around here)

The first model comprises only the control variables. None of the variables are statistically significant, except the coefficient for France (not reported), due to the fact this country has been very active on the front of democratic reforms between 1990 and 2010. The number of veto players in the government has no effect on the number of reforms adopted, the level of growth does not reach statistical significance, and there is no evidence that the ideological orientation of the legislature plays any part in the number of reforms adopted. The absence of the effect of the number of partisan veto players tends to go against the 
assumptions of the literature stating that more veto players mean more stability. This suggests that institutional reforms actually do not work in the same way as expected by Tsebelis, in that the partisan veto player/stability relationship does not hold here.

Model 2 investigates the effect of the evolution of the average level of satisfaction with democracy ${ }^{5}$ and the number of institutional reforms adopted in a legislature. The results do not support the first hypothesis, as there is no evidence of a statistically significant relationship between drops of satisfaction with democracy and the number of reforms adopted. The third model shows that, consistent with hypothesis 2 , the evolution of volatility has a positive and statistically strong significant effect on the number of reforms adopted by a legislature: the more volatility rises compared to the previous election, the more reforms adopted: a rise of volatility by 1 percentage point is associated with a $4 \%$ increase in the number of reforms. The predicted number of reforms for different levels of volatility has been calculated, holding all other variables at their means (Figure 1).

(Figure 1 around here)

The graph of the predicted number of events shows that when volatility decreases by $80 \%$, the model predicts that 0.9 reforms will be adopted, while when volatility rises from one election to another by $200 \%$, this number rises to 2.5 . Beyond a rise of $200 \%$ of the level of volatility from one election to another, the interval of confidence becomes much wider, meaning that the relationship between volatility and number of reforms is more indiscriminate.

The fourth model investigates the effect of political alternation, and confirms the third hypothesis, as the effect of alternation is positive with strong statistical significance. Holding all variables at their means, the predicted number of reforms adopted in the absence of political alternation is 0.8 , while when political alternation occurs; this figure rises to 1.5 , hence almost doubling the average number of reforms adopted. ${ }^{6}$

Model 5 includes both the evolution of total volatility and political alternation. The effect of both variables is, again, statistically significant. Finally, in model 6, including all explanatory variables, the previous results are confirmed, with a very similar predicted number of reforms both according to the level of volatility and in the presence of alternation in power. Investigations to check whether the effect of alternation was conditional upon the shift in the level of volatility have been conducted. Although a Student's t-test suggests that 
the level of total volatility tends to be higher when alternation occurs, ${ }^{7}$ no evidence of interaction between these two key variables was found, suggesting an independent effect of the rise of the level of uncertainty in which parties compete, and of political alternation, on the number of reforms adopted by legislature.

Substantively, these models enable us to reach several conclusions. First of all, there is consistent empirical evidence that short-term electoral shocks, and switch of preferences of the elites in power, do have a statistically, but also substantially significant impact on the number of institutional reforms adopted in a legislature. Secondly, the variations of the "moods" of public opinion regarding satisfaction with democracy do not impact this number, while political alternation and the evolution of the level of volatility do. This does necessarily mean that shifts in the level of satisfaction with democracy do not have any influence on institutional activism. To use Shugart's terminology (2003), the overall level of satisfaction with democracy (and not its evolution) may well be an inherent factor of reform (creating in the long run favourable conditions for institutional reforms to happen), whereas alternation and the rise of volatility are contingent factors of reform. This in turn suggests that political elites are sensitive to the swings in the electoral arena when deciding to promote institutional reform, while changes in public opinion are not sufficient to influence political elites. Rising electoral volatility can be thought of as the tangible manifestation of changes in the electoral arena, implying rising uncertainty for political parties. Alternation, as it brings into power parties with different preferences regarding institutional reforms, provides a window of opportunity to reform for parties previously in opposition. Moreover, the effect of these variables holds when they are both included, and therefore controlled for, in the various statistical models. This is particularly significant when it comes to the interpretation of the role of volatility: this means that whether or not an alternation in power occurs at the beginning of a legislature, the rise of electoral uncertainty has an independent influence on the number of reforms.

\section{Testing for the robustness of the models across reform categories}

The main objection that could be made to this analysis is that the results may be highly dependent upon the sample of reforms included in the analysis. Indeed, as the reforms included are diverse, the issue of causal homogeneity should be taken into account: the results may be disproportionately influenced by the inclusion or non-inclusion of certain reforms. In order to see if the results are consistent over dimensions, the same regressions have been run, 
omitting each time one of the six categories of reform. I then ran the analyses adding an additional category of reform: the changes in the public subsidies of political parties. This category of reform was also present in the SIEPOL database, but that can be considered as a more peripheral aspect of the rules regulating democracy compared to the six categories that have been used in the initial sample (See online Appendix 4 and 5). Additionally, I checked for the robustness of the models when the direction of the reforms is taken into account. The SIEPOL dataset classifies the direction of reforms into two categories: inclusive reforms (opening the process of decision-making to the citizen) and exclusive reforms (closing-off the decision-making arena from influence of the citizens, Bedock, Mair, and Wilson 2012, 5). Finally, I ran the regressions using only the reforms labeled as substantial reforms in the SIEPOL dataset as the dependent variable (See online Appendix 6 and 7). ${ }^{8}$

All of the coefficients for volatility and political alternation are systematically statistically significant for the regressions reproducing models 3 and 4 , meaning that the relationship found between volatility, political alternation, and the number of reforms holds even when a specific dimension of reform is omitted. The effects found are quite stable across models, in particular for volatility. The reproduction of model 5 omitting one dimension of reform each time tends to confirm in each case the independent effect of volatility and alternation. The two exceptions concern the models excluding decentralization and direct election reform, in which alternation is just above the threshold of statistical significance. When reforms of public funding of political parties are added in the sample of reforms, the statistically significant relationship between volatility, alternation, and frequency of reform is confirmed. The coefficients are extremely similar to the general model for volatility, while the effect of alternation is even slightly stronger than in the models presented previously.

The models also appear to be broadly consistent when only inclusive reforms are taken into account, even though the shift of the level of volatility is slightly above the level of statistical significance in models 5 and 6 (online Appendix 6). The impact of alternation seems to be even stronger than in the original models: holding all other variables at their means, the model predicts the adoption of 0.45 reforms in the absence of alternation, and 1.1 reforms, hence more than doubling the predicted number of reforms, when there is an alternation in power at the beginning of the legislature. Finally, when only substantial reforms are taken into account (online Appendix 7), the coefficients for volatility and political alternation are again statistically significant. The impact of alternation is even stronger than in the general models: it is shown that in the absence of alternation, the model predicts no 
substantial reforms, whereas when alternation occurs, the model predicts 0.5 substantial reform.

Therefore, the tests for the robustness of the models clearly confirm the results previously discussed both when categories of reform are added to and subtracted from the initial sample. Without denying that not all of these reforms, dimension by dimension, are necessarily driven by the exact same factors, one can draw a general model of the impact of short-term factors on institutional reforms and apply it to multiple categories at once.

\section{Volatility shifts, alternation, and reforms: an illustration of the mechanisms}

How do these two mechanisms (rise in volatility, and alternation) work concretely to bring about more institutional reforms? A precise answer would require in-depth case study investigation. However, it is useful to go back to descriptive statistics, and to have a look at the "extreme legislatures", i.e. at the legislatures in which an unusually high number of institutional reforms were adopted. When observing the 18 of legislatures in which three reforms or more were adopted, the descriptive evidence is clear: 12 out these 18 legislatures were placed under the sign of political alternation (vs. only $42 \%$ of the 116 legislatures of the total sample), while volatility has risen on average by $38 \%$ compared to the previous election in these seven legislatures (rise of $19 \%$ on average for the 116 legislatures included in the database, see Table 3).

(Table 3 around here)

The British and the Italian example offer interesting illustrations of our findings, and the mechanisms they imply: UK for alternation, and Italy for volatility. In 1997, the UK Labour party came into power after 18 years of one-party, conservative rule, with an unprecedented majority of 418 seats (almost two thirds of total seats). Undoubtedly, Labour held very different preferences regarding the desirable shape of the institutional system compared to the Conservative party that had been in power since 1979. Electoral promises in the Labour manifesto of 1997 contained the following statement: "Labour is committed to the democratic renewal of [the] country through decentralization and the elimination of excessive government secrecy". Concrete promises to "clean up politics" included the end of the hereditary principle in the House of Lords, reform of party funding, devolution for Scotland and Wales, elected mayors, and a more independent and accountable local government. ${ }^{9}$ By the end of the legislature, six institutional reforms had been adopted, touching upon multiple 
dimensions of the institutional system: reforms instituting devolution in Scotland and Wales with numerous competences and regional assemblies in England, electoral reforms introducing mixed-member electoral systems in Scotland and Wales, a parliamentary reform abolishing hereditary peerages, but also the introduction of the direct election of the mayor of London, and new provisions facilitating postal and proxy voting (Bedock, Mair, and Wilson 2012). Alternation has provided a clear push and political opportunity for Labour, a party that held distinctive preferences over institutional reforms built during their time in opposition, to implement a political programme including multiple institutional changes.

Italy experienced its third alternation in a row in 2001, with the arrival in power of a coalition of the center-right including Forza Italia, Alleanza Nazionale, Lega Nord, and the centrist UDC. The previous coalition in government, the center-left, had led four unstable, multiparty and heterogeneous coalition governments since 1996. The volatility had risen from $8.8 \%$ in 1996 to no less than $22 \%$ in 2001, in the context of an extremely fragmented and instable electoral landscape in Italy. Institutional reforms, in this context of great electoral uncertainty, were high on the agenda for all government parties: the Lega was pushing towards fiscal federalism and more powers to the regions, the UDC was looking for ways to re-establish a proportional electoral system, Forza Italia and Berlusconi were advocating for a much stronger role of the executive power and the PM, while AN was trying to defend its new respectability in the Italian party system (Bedock 2011, Renwick, Hanretty, and Hine 2009). Electoral uncertainty reduces the temporal horizon of political actors, who are not sure of being able to keep their place in the system in the near future. As such, this context of uncertainty provided both incentives and opportunities to try to transform the Italian institutional system, and be risk-prone rather than risk-averse. As a result, several far-reaching reforms were adopted in order to accommodate everyone in the governing coalition: complete replacement of the 1993 electoral system by a PR system with bonus, and the modification of 50 constitutional articles, that would have turned Italy into a federal state, removed bicameral symmetry, and reinforced considerably the power of the PM (Vassallo 2005). ${ }^{10}$ This process of accommodation of multiple interests into a wide package of reforms may, in turn, contribute to the explanation of why there is no link between the number of parties in government and the frequency of reform.

\section{Conclusion}


This study has provided clear empirical evidence of a link between shifts in the electoral arena, measured by rising uncertainty, shifts of preferences of the actors in power, measured by political alternation, and the subsequent number of institutional reforms adopted in a legislature. The fact that drops in the level of political support does not directly play a role in explaining the number of reforms, shows that elites react to more tangible changes of the political environment, and more particularly to electoral shifts, rather than to the shortterm evolutions of public opinion.

Secondly, the results are consistent and robust across categories, showing that drawing a general model linking short-term shocks and institutional reforms is possible, even when the categories included in the sample are numerous and varied. These findings should, of course, be qualified, enriched and nuanced by further investigations. Future agendas of research include the inquiry into the mechanisms behind these short-term factors and institutional reforms, a more careful description of the paths of reform according to the types of reforms and the processes of reform chosen, the test of these results on a wider timeframe and including a wider range of democracies, and, ideally, the inclusion in the analysis of failed attempts of reforms as well as successful ones. Future analyses will also have to disentangle in more detail the causal mechanisms between shifts of public opinion, volatility, and alternation, and the complex interaction between act-contingent and outcome contingent motivations of political elites behind reforms.

Compared to the main existing theories of institutional change, which have shown that institutional change may occur through a long-term evolutionary process, or as a result of punctuations, this article makes a contribution in explaining when change is more frequent. It provides evidence of the strong influence of short-term shocks and everyday politics in the occurrence of institutional change. We find that political elites appear to react to their environment by using institutional reforms, have different preferences regarding institutional reforms, and have more frequent use of institutional reforms when actors in power hold distinctive preferences compared to the incumbents (alternation), and when the level of uncertainty of the electoral environment rises (rise of volatility). Therefore, events disturbing public opinion, when translated into voting, help in promoting institutional reforms. To summarize, short-term factors provide a decisive push, by fostering a favorable context and decisive opportunities to adopt reforms. 
Acknowledgements :

I thank David Farrell for his very useful comments on an early version of the paper presented in the EUI in the colloquium "Political parties and institutions", all the participants of the workshop "Parties, Party Systems and the Quality of Democracy" as well as the participants of the Journée doctorale Sciences Po - ULB in Brussels for their great suggestions that have helped me greatly in the course of revision, and finally, Lukas Leeman for his invaluable advice on the statistical part in particular.

\section{References}

Andrews, Josephine T., and Robert W. Jackman. 2005. "Strategic Fools: Electoral Rule Choice Under Extreme Uncertainty." Electoral Studies 24 (1): 65-84.

Bartolini, Stefano, and Peter Mair. 1990. Identity, Competition and Electoral Availability: The Stabilisation of European Electorates, 1885-1985. Cambridge: Cambridge University Press.

Bawn, Kathleen. 1993. "The Logic of Institutional Preferences: German Electoral Law as a Social Choice Outcome.” American Journal of Political Science 37 (4): 965-89.

Bedock, Camille. 2011. "Du mattarellum au porcellum : une comparaison des réformes électorales de 1993 et 2005 en Italie." Pôle Sud nº 34 (1): 27-44.

. 2014. "Reforming Democracy: Institutional Engineering in Western Europe, 19902010”. Florence: European University Institute.

Bedock, Camille, Peter Mair, and Alex Wilson. 2012. "Institutional Change in Advanced European Democracies: An Exploratory Assessment." EUI Working Papers RCSAS EUDO Democracy Observatory (2012/11). http://cadmus.eui.eu/handle/1814/20817.

Benoit, Kenneth. 2007. "Electoral Laws as Political Consequences: Explaining the Origins and Change of Electoral Institutions." Annual Review of Political Science 10: 363-90.

Blais, André, Agnieszka Dobrzynska, and Indridi Indridason. 2004. "To Adopt or Not to Adopt Proportional Representation: The Politics of Institutional Choice." British Journal of Political Science 35 (1): 182-90.

Boix, Carles. 1999. "Setting the Rules of the Game: The Choice of Electoral Systems in Advanced Democracies." American Political Science Review 93 (3): 609-24.

Bol, Damien. 2013. "Electoral Reform, Values and Party Self-Interest." Party Politics, December, 1354068813511590.

Bowler, Shaun, Todd Donovan, and Jeffrey A Karp. 2006. "Why Politicians Like Electoral Institutions: Self Interest, Values, or Ideology?” Journal of Politics 68 (2): 434-46.

Bowler, Shaun, Todd Donovan, and Jeffrey A. Karp. 2002. "When Might Institutions Change? Elite Support for Direct Democracy in Three Nations." Political Research Quarterly 55 (4): 731-54.

Calvo, Ernesto. 2009. "The Competitive Road to Proportional Representation." World Politics 61 (2): 254-95. 
Cameron, A. Colin, and Pravin K. Trivedi. 2001. "Essentials on Count Data Regression." In $A$ Companion to Theoretical Econometrics, by Badi H. Baltagi, 331-48. Oxford: Blackwell.

Colomer, Josep. 2001. "Disequilibrium Institutions and Pluralist Democracy." Journal of Theoretical Politics 13 (3): 235-47.

2005. "It's Parties That Choose Electoral Systems (or, Duverger's Laws Upside Down)." Political Studies 53 (1): 1-21.

Dalton, Russell J. 1999. "Political Support in Advanced Industrial Democracies." In Critical Citizens: Global Support for Democratic Governance, edited by Pippa Norris, 57-77. Oxford: Oxford University Press.

Greif, Avner, and David D. Leitin. 2004. “A Theory of Endogenous Institutional Change.” American Political Science Review 98 (4): 633-52.

Hilbe, Joseph M. 2011. Negative Binomial Regression. 2nd ed. Cambridge University Press.

Hooghe, Marc, and Kris Deschouwer. 2011. "Veto Players and Electoral Reform in Belgium." West European Politics 34 (3): 626-43.

Huntington, Samuel P. 1965. "Political Development and Political Decay." World Politics 17 (3): $386-430$.

Immergut, Ellen M. 1990. "Institutions, Veto Points, and Policy Results: A Comparative Analysis of Health Care.” Journal of Public Policy 10 (4): 391-416.

1992. Health Politics: Interests and Institutions in Western Europe. Cambridge: Cambridge University Press.

Jacobs, Kristof, and Monique Leyenaar. 2011. "A Conceptual Framework for Major, Minor, and Technical Electoral Reform." West European Politics 34 (3): 495-513.

Jones, Bryan D., and Frank R. Baumgartner. 2012. "From There to Here: Punctuated Equilibrium to the General Punctuation Thesis to a Theory of Government Information Processing." Policy Studies Journal 40 (1): 1-20.

Lijphart, Arend. 1999. Patterns of Democracy. Government Forms and Performance in Thirty-Six Countries. New Haven: Yale University Press.

Norris, Pippa. 2011. "Cultural Explanations of Electoral Reform: A Policy Cycle Model." West European Politics 34 (3): 531-50.

Pedersen, Mogens N. 1979. "The Dynamics of European Party Systems: Changing Patterns of Electoral Volatility." European Journal of Political Research 7 (1): 1-26.

Pilet, Jean-Benoit. 2008. "The Future Is Imagination, the Present Is Reality: Why Do Big Ruling Parties Oppose Majority Systems? A Belgian Case Study.” Representation 44 (1): 41-50.

Pilet, Jean-Benoit, and Damien Bol. 2011. "Party Preferences and Electoral Reform: How Time in Government Affects the Likelihood of Supporting Electoral Change." West European Politics 34 (3): 568-86.

Rahat, Gideon. 2004. "The Study of the Politics of Electoral Reform in the 1990s: Theoretical and Methodological Lessons." Comparative Politics 36 (4): 461-79.

Remmer, Karen L. 2008. "The Politics of Institutional Change: Electoral Reform in Latin America 1978-2002." Party Politics 14 (1): 5-30. 
Renwick, Alan. 2010. The Politics of Electoral Reform: Changing the Rules of Democracy. 1st Edition. Cambridge: Cambridge University Press.

—. 2011. "Electoral Reform in Europe since 1945." West European Politics 34 (3): 45677.

Renwick, Alan, Chris Hanretty, and David Hine. 2009. "Partisan Self-Interest and Electoral Reform: The New Italian Law of 2005.” Electoral Studies 28 (3): 437-47.

Rokkan, Stein. 1970. Citizens, Elections, Parties. Approaches to the Comparative Study of the Processes of Development. New York: David McKay.

Roller, Edeltraud. 2003. "Conceptualizing and Measuring Institutions of Democratic Governance: A Critical Review and Empirical Validation of Veto Player Indexes.” In ECPR Joint Sessions of Workshops. Edinburgh.

- 2005. The Performance of Democracies: Political Institutions and Public Policies. Oxford: Oxford University Press.

Shugart, Matthew S, and Martin P Wattenberg. 2003. Mixed-Member Electoral Systems: The Best of Both Worlds? Oxford University Press, USA.

Shugart, Matthew S. 2003. "Extreme Electoral Systems and the Appeal of the Mixed-Member Alternative." In Mixed-Member Electoral Systems: The Best of Both Worlds?, edited by Matthew S. Shugart and Martin P. Wattenberg, 25-53. Oxford: Oxford University Press.

Steinmo, Sven. 2010. The Evolution of Modern States: Sweden, Japan, and the United States. Cambridge: Cambridge University Press.

Streeck, Wolfgang, and Kathleen Thelen, eds. 2005. Beyond Continuity: Institutional Change in Advanced Industrial Economies. Oxford: Oxford University Press.

Tsebelis, George. 1990. Nested Games: Rational Choice in Comparative Perspective. Berkeley: University of California Press.

- 2002. Veto Players: How Political Institutions Work. Princeton: Princeton University Press.

Vassallo, Salvatore. 2005. "The Constitutional Reforms of the Center-Right." In Quo Vadis?, edited by Carlo Guarnieri and James L. Newell, 117-35. Bologna: Istituto Carlo Catteneo. 
Table 1. Number of institutional reforms adopted by legislature in 18 Western European democracies, 1990-2010

\begin{tabular}{c|c|c} 
Reforms by legislature & N & $\%$ \\
\hline 0 & 43 & 37.1 \\
1 & 37 & 31.9 \\
2 & 18 & 16.4 \\
3 & 9 & 6.9 \\
4 & 3 & 2.6 \\
5 & 2 & 1.7 \\
6 & 3 & 2.6 \\
7 & 1 & 0.9 \\
\hline Total & $\mathbf{1 1 6}$ & $\mathbf{1 0 0 \%}$ \\
\hline
\end{tabular}

Source: my own elaboration of the SIEPOL database (Bedock, Mair, Wilson, 2012) $)^{11}$ 
Table 2. Determinants of the number of institutional reforms adopted by legislature in Western Europe (1990-2010)

\begin{tabular}{|c|c|c|c|c|c|c|}
\hline & Model 1 & Model 2 & Model 3 & Model 4 & Model 5 & Model 6 \\
\hline $\begin{array}{l}\text { Evolution of the level of satisfaction } \\
\text { with the way democracy works in \% }\end{array}$ & & $\begin{array}{c}1.007 \\
(0.99-1.02)\end{array}$ & & & & $\begin{array}{c}1.007 \\
(0.99-1.02)\end{array}$ \\
\hline Evolution of the total volatility in $\%$ & & & $\begin{array}{c}1.004 * * * \\
(1.00-1.01)\end{array}$ & & $\begin{array}{c}1.003 * * \\
(1.00-1.01)\end{array}$ & $\begin{array}{c}1.003 * * \\
(1.00-1.01)\end{array}$ \\
\hline Alternation in government & & & & $\begin{array}{l}1.818 * * * \\
(1.19-2.78)\end{array}$ & $\begin{array}{c}1.541 * \\
(0.99-2.40)\end{array}$ & $\begin{array}{c}1.474 * \\
(0.96-2.26)\end{array}$ \\
\hline Number of parties in the government & $\begin{array}{c}1.088 \\
(0.82-1.43)\end{array}$ & $\begin{array}{c}1.024 \\
(0.77-1.36)\end{array}$ & $\begin{array}{c}1.101 \\
(0.85-1.43)\end{array}$ & $\begin{array}{c}1.007 \\
(0.76-1.32)\end{array}$ & $\begin{array}{c}1.038 \\
(0.80-1.34)\end{array}$ & $\begin{array}{c}0.990 \\
(0.76-1.29)\end{array}$ \\
\hline
\end{tabular}

Ideological orientation (ref. cat.:

left/center left)

Right/center-right government

$1.156 \quad 1.210$

1.114

1.143

1.120

1.162

Grand Coalition government

$(0.72-1.87) \quad(0.76-1.94)$

(0.70-1.76)

(0.72-1.82)

(0.71-1.77)

(0.75-1.80)

$\begin{array}{cc}1.091 & 0.990 \\ (0.51-2.34) & (0.46-2.11)\end{array}$

1.132

0.975

1.037

0.943

1.097

1.075

(0.56-2.30)

(0.47-2.03)

(0.51-2.09)

(0.48-1.46)

Growth

(0.99-1.23) (0.96-1.20)

1.104*

1.097*

1.103*

1.081

(0.99-1.23)

(0.98-1.22)

(0.99-1.23)

(0.97-1.20)

\begin{tabular}{lcccccc}
\hline Observations & 116 & 116 & 116 & 116 & 116 & 116 \\
Alpha & 0.209 & 0.169 & 0.110 & 0.159 & 0.102 & 0.051 \\
& $(0.06-0.73)$ & $(0.04-0.77)$ & $(0.01-0.86)$ & $(0.04-0.71)$ & $(0.01-0.87)$ & $(0.00-3.48)$ \\
& & & & & & \\
Pseudo R-squared & 0.08 & 0.09 & 0.11 & 0.11 & 0.12 & 0.12 \\
Cox-Snell Pseudo R-squared & 0.23 & 0.24 & 0.28 & 0.28 & 0.30 & 0.32 \\
Likelihood-Ratio chi2 & 30.01 & 31.91 & 38.36 & 37.58 & 42.10 & 44.40 \\
Prob>chi2 & 0.092 & 0.089 & 0.017 & 0.020 & 0.009 & 0.007 \\
\hline \hline
\end{tabular}

Note: The results of the coefficients are reported in terms of incidence rate ratio. $95 \%$ confidence intervals are in parentheses. The dependent variable is the total number of reforms adopted by legislature between 1990 and 2010 . Other control variables not reported here include 18 country dummies. ${ }^{*} \mathrm{p}<0.1$; **p $<0.05 ; * * \mathrm{p}<0.01$. 
Figure 1. Predicted number of reforms according to the evolution of total volatility (model 3)

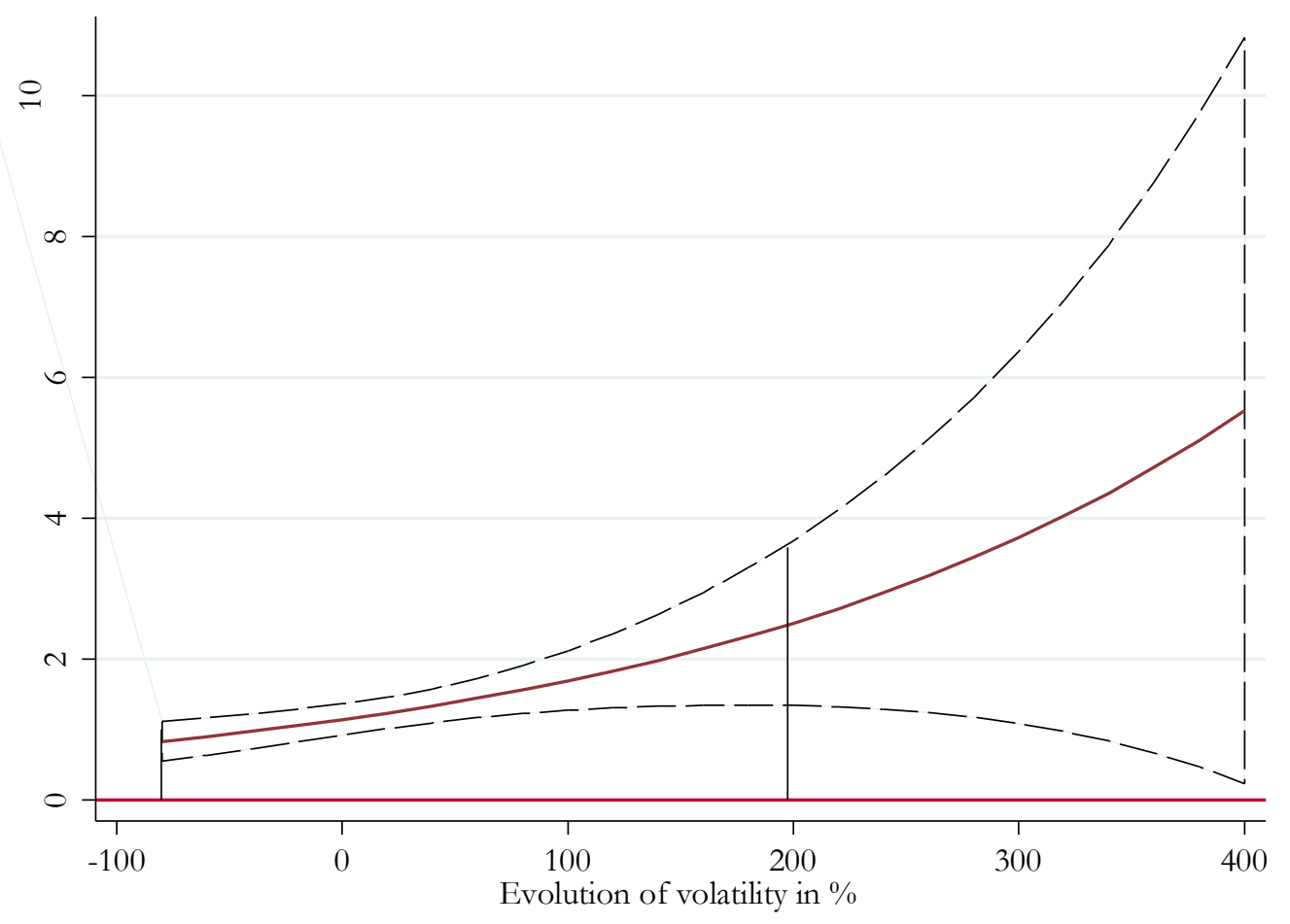

Note: the values for the evolution of volatility vary between a $77 \%$ decrease and a $357 \%$ rise. 
Table 3. Evolution of volatility and political alternation by number of reforms adopted by legislature

\begin{tabular}{cccc} 
Reforms by legislature & $\begin{array}{c}\text { Legislatures with } \\
\text { alternation in } \%\end{array}$ & $\begin{array}{c}\text { Average evolution of } \\
\text { volatility in } \%\end{array}$ & N \\
\hline All legislatures & $42 \%$ & $+19 \%$ & 116 \\
\hline $\begin{array}{c}\text { Number of reforms } \geq 3 \\
\text { (Top 15\%) }\end{array}$ & $66 \%$ & $+38 \%$ & 12 \\
\hline \hline
\end{tabular}




\begin{abstract}
${ }^{1}$ It may seem crude to characterize it first and foremost as a switch in preferences of the elites and parties composing the government. Indeed, there is no doubt that political alternation is influenced by shifts in public opinion (as the literature on retrospective voting has evidenced over the years). Yet, disentangling the two aspects would require much more sophisticated data and statistical techniques, so for that reason, I have privileged the most straightforward interpretation of alternation.
\end{abstract}

${ }^{2}$ A complete description of the dataset, and an exhaustive list of the reforms that were taken into account is available in the paper by Bedock, Mair, and Wilson 2012, accessible online: http://cadmus.eui.eu/handle/1814/20817. See also the Phd thesis of Bedock (2014).

${ }^{3}$ When the dependent variable is a dummy variable opposing reform vs. no reform legislatures, there is evidence that there is no statistically significant impact of the shifts of volatility on the propensity to have at least one reform in a given legislature, whereas these appear to be linked in a statistically significant way to the number of reforms adopted in a legislature in the models presented. Similar results appear when legislatures with at least two reforms vs. legislatures with one reform or less are used as the dependent variable.

${ }^{4}$ There is not, yet, a really well-established literature on the link between economic crises and institutional reforms, but this constitutes one of the most promising research tracks for academics interested in the link between macroeconomic developments, popular legitimacy, and institutional reforms. See, for example, the recent workshop of Kristof Jacobs and David Farrell called "Crowd-pleasers or key janglers? The impact of drops in political legitimacy on democratic reform and their consequences".

${ }^{5}$ In models not reported here, I tested for the effect of the lagged evolution of satisfaction with democracy, which did not lead to meaningful results either.

${ }^{6}$ In models not reported here, I tested for the effect of time since the last alternation on the number of reforms adopted, to see whether what explains the effect of alternation is the fact that elites have been excluded from power for a long time, as argued by Bol and Pilet (2011). There is no evidence that the time since the last alternation took place has a statistically significant relationship with the number of reforms adopted.

${ }^{7}$ When there is no alternation, the average rise of volatility is $1.8 \%$. When alternation occurs, there is an average rise of volatility of $43.6 \%$.

${ }^{8}$ For the definition of inclusive reforms in the SIEPOL dataset, see online Appendix 1.

${ }^{9}$ See the Labour manifesto for the general elections of 1997 in the following link: http://www.labourparty.org.uk/manifestos/1997/1997-labour-manifesto.shtml

${ }^{10}$ This constitutional reform was eventually repelled in a constitutional confirmative referendum, as authorized in the Italian constitution when the majority of $2 / 3$ rds of the parliament is not reached. $61.3 \%$ of Italian citizens rejected the constitutional reform in June, 2006.

${ }^{11}$ Compared to the previous version of the SIEPOL database, two additional reforms that happened in Ireland were included in the analysis: the reform of the constitutional amendment to recognize the role of local government adopted in 1999 and the 2001 Local Government Act. 